\title{
ラット自発運動の生体防御機構に及ぼす慢性影響
}

\author{
鈴木克彦町田和彦刏屋美枝子 \\ 有倉恵子稲恭宏塚本和正

\section{CHRONIC EFFECTS OF VOLUNTARY EXERCISE ON SRBC-INDUCED HOST DEFENSE REACTIONS IN RATS}

\author{
Katsuhiko Suzuki, Kazuhiko Machida, Mieko Kariya, \\ Keiko Arikura, Yasuhiro Ina and Kazumasa Tsukamoto
}

\begin{abstract}
A study was conducted to evaluate the chronic effects of regular physical activity on nonspecific and specific immune responses. Male Fischer rats (SPF) exercised voluntarily on running wheels for 4 months, and were then injected intraperitoneally with sheep red blood cells (SRBC), followed by measurement of the host defense functions at $-2 \mathrm{~d}, 3 \mathrm{~h}, 24 \mathrm{~h}$ and $4 \mathrm{~d}$ of antigen stimulation. The following results were obtained:

1) The ability of circulating neutrophils to produce superoxide measured by the spontaneous NBT test showed an earlier and higher $(\mathrm{p}<0.05)$ rise after SRBC injection in the exercise group, suggesting that neutrophils were activated in vivo more promptly against foreign-body invasion. This might reflect a priming response of neutrophils at the early phase of SRBCinduced host defense reactions modulated by the previous regular exercise.

2) The ability of neutrophils to produce superoxide in response to in vitro stimulation with Staphylococcus aureus $209 \mathrm{P}$ was markedly reduced during inflammatory response in the sedentary group, whereas that in the exercise group was maintained at a constant level. The value at $4 \mathrm{~d}$ after SRBC injection in the sedentary group was decreased to more than $20 \%$ below the baseline $(p<0.02)$. In addition, a significantly $(p<0.02)$ lower value than that in the exercise group was shown, although phagocytic activity was similar in the two groups. This suggested that neutrophil bactericidal activity was decreased in the sedentary group.

3) Plasma IgG levels in the exercise group were consistently and significantly $(\mathrm{p}<$ 0.0001 ) higher by about $30 \%$ than those in the sedentary group, regardless of SRBC injection. This suggested an enhanced host defense status by regular exercise.

4) The specific humoral immune response to SRBC injection was assessed in terms of hemagglutination and plasma IgM levels, but no significant differences were shown between the groups.
\end{abstract}

(Jpn. J. Phys. Fitness Sports Med. 1993, $42: 145 \sim 154$ )

key words : voluntary exercise, neutrophils, free radicals, immunoglobulins, rats

\section{I. 粕}

言

運動習慣と免疫に関する研究は, 中高年者の健 康の保持・増進やスポーツ選手の健康管理の問題 を背景として，近年関心の持たれている研究分野 の一つである．最近の総説によれば，激しいトレ
ーニングを継続すると免疫機能は損なわれるが， 一方で適度な運動習慣は免疫機能を高める可能性 があると指摘されている $2,7,11,14,16)$. 後者の具体例 としては, 呼吸器感染症䍜患期間の减少とナチュ ラルキラー細胞活性の上昇 ${ }^{24)}$ ，好中球活性酸素産 生能と血清 $\operatorname{IgG}$ 值の上昇 ${ }^{3)}$, 血清免疫グロブリン
早稲田大学人間科学部衛生学公衆衛生学教室 干359 埼玉県所沢市三ヶ島2-579-15
Department of Hygiene and Public Health, School of Human Sciences, Waseda University 2-579-15 Mikajima, Tokorozawa, Saitama 359 
值の上昇 ${ }^{22)}$ 等の報告がある. しかし顕著な効果は 認められなかったといら報告もあり ${ }^{15,17,34) ， ま た ゙ ~}$ 一致した見解は得られていないといらのが現状で ある.

一ロに運動習慣と言っても，その強度，頻度， 期間, 種類等の条件は多様であり，また生体防御 機構も多面的・重層的で，宿主の条件によって変 動し易いため，運動習慣の真の影響を把握するこ とは容易ではない，本来ならばヒトを対象として 検討を行らべきであるが，個人差が大きい上に実 験手法上の制約もあり，特に健康づくりのための 適度な運動の慢性影響を検討する場合には，適切 な対照群の設定や一定条件の運動を長期間継続す ることが難しく，微妙な変化の把握が困難である ことが多い。

そこで本研究では, 遺伝的条件と生活条件を敩 密に規定でき，かつ in vivo で免疫応答を誘導で きる動物実験の利点を生かして，運動習慣の影響 を検討することにした ${ }^{299}$. 動物実験で報告されて きた適度な運動習慣の効果としては, 細菌感染に 対する生存率の増加“), 腫瘍細胞移植に対する增 殖遅延効果 ${ }^{101}$, 免疫二次応答時の特異抗体産生能 の上昇 ${ }^{18)}$, 肺胞マクロファージの細胞数, 食食能 およびインターロイキン 1 産生能の上昇 ${ }^{20,31)}$ 等が ある. しかし好中球機能や免疫グロブリン值への 影響については, 生体防御機構の重要な構成要素 であるにもかかわらず，動物実験ではまだ倹討さ れていないよらである.

本研究では, 自発運動 (運動群) と安静 (非運 動群）の両条件下で 4 カ月間飼育した成熟ラット に, T細胞依存性抗体産生反応を誘導する羊赤血 球 (Sheep Red Blood Cells : SRBC) を接種して 実験的に免疫応答を誘導し，それに伴って変動す る感染防御を担ら主要因子および機能の経時的な 測定を通じて，適度な運動習慣によって非特異的 な生体防御反応とそれに引き続く特異抗体の産生 が強化されるか否かを検討した。

\section{II. 方法}

\section{A. 実験勤物および飼育条件}

8 週龄の Fischer 系 SPF 雄ラット（日本チャ
ールズ・リバー社)を, 1 週間の予備飼育の後, 運 動群と非運動群（対照群）に15匹ずつ体重を揃え て分けた. 運動群は 1 周 $1 \mathrm{~m}$, 幅 $15 \mathrm{~cm}$ の水車式 回転籠（夏目製作所 LB 5-1) で，非運動群はラッ ト代謝ケージ（高さ $20 \times 20 \times 25 \mathrm{~cm}$, 夏目製作所 $\mathrm{KN}-646 \mathrm{~B})$ で, 各群それぞれ 1 匹飼いで 4 力月間 飼育した。飼育環境は, 外部の騒音を遮断し感染 を制御したセミバリア室内で, 室温 $25 \pm 2{ }^{\circ} \mathrm{C}$, 湿 度 $55 \pm 10 \%$ ，さらに 9 時から 21 時までの 12 時間照 明による明暗周期を設定し，一定条件下で飼育し た. またラットは飼育環境の変化に敏感に反応し, その結果自発的でない運動を行って運動量を極端

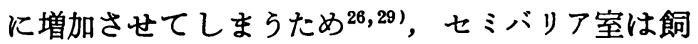
育全期間にわたり本実験専用とし，飼育作業以外 の立ち入りを制限した，慨は高圧蒸気滅菌済固形 飼料（日本クレア CE-2）を，水は蒸留水を両者 ともに自由摂取で与えた，飼育期間中，運動量測 定装置の回転数を自発運動量として週 2 度記録し た.また体重は月に 2 度, 摂食量と摂水量は月に 1 度測定した。

\section{B. 異物接程条件および経時的測定の概要}

経時的測定は，一過性の運動や概日リズムの影 響を避けるため，ラットの非活動時（明時）の定 刻に行った。異物としては，20\% SRBC（日本ハ イオテスト）を無菌的に調製し，ラットの腹腔内 に体重 $100 \mathrm{~g}$ 当り $0.5 \mathrm{ml}$ 注射した. その 2 日前, 接種後 3 時間目， 24 時間目， 4 日目の計 4 点でラ ットの尾静脈より採血し, 白血球数とその構成比, 好中球の食食能と活性酸素産生能, 液性因子とし ては血漿で免疫グロブリン值 (IgG, IgM) と補体 系の中心成分 C 3 を測定した. 接種後 4 日目には, エーテル麻酔下でラットの股動脈より全採血し， 血清を分離して抗 SRBC 抗体価の測定に用いた。

\section{C. 白血球数と好中球殺菌能の測定法}

総白血球数はメランジュール法, 白血球構成比 の算定はメイ・ギムザ染色法, 好中球の殺菌能検 查法としては NBT 還元試験を松田 ${ }^{9}$ の毛細管法 に準じて実施した. NBT 還元試験は, 食細胞によ って生成されるスーパーオキサイドと NBT が特 異的に反応し, 細胞内に有色の凝固物（フォルマ ザン）を形成する酸化還元反応を原理とする ${ }^{6)}$. 
本実験では, 普通寒天培地で一晚培養した黄色ブ ドウ球菌 (St. aureus) $209 \mathrm{P}$ (カタラーセ陽性, $\mathrm{H}_{2} \mathrm{O}_{2}$ 非産生株でより強く活性酸素の生成を促す) を刺激粒子として用いる刺激 (stimulated) 試験 と，ブドウ球菌を加えない対照としての無刺 激 (spontaneous) 試験を同時に実施した. ブドウ球 菌は $1 \times 10^{9}$ 個 $/ \mathrm{m} l$ の濃度で最終濃度 $0.1 \%$ NBT (Nitroblue Tetrazolium, Sigma Grade III) の PBS (pH 7.2) 溶液に添加した. その NBT 溶夜を 等量の静脈血と一パリン処理毛細管 (Dramond 社) 内で混和し， $37^{\circ} \mathrm{C} て ゙ 20$ 分間反応させた後, 塗 抹標本を作成してライト・ギムザ染色を行った. 本試験は，オプソニン活性も測定結果に反映でき る全血をサンプルとして用いることができ，かつ 採血直後に反応を開始するため, 生体内での機能 発現により近い活性を測定できる。また 1 回の測 定に要する血液もへマトクリット毛細管 1 本分で 済むため, 経時的測定を行ってもラットの負担を 最小限に抑えられるといら利点がある. 標本は 1,000倍で検鏡し， 1 標本で50個の好中球について フォルマザンの形成を観察した。 その際, 朝永 ${ }^{301}$ の組織化学的半定量法に準ずる分析パネル（当教 室作成）を参照しながら，フォルマザンの沈着パ ターンを類型化して活性酸素産生能をスコア化し た.またブドウ球菌で好中球を刺激した場合に は, 細胞内に取り込まれた細菌粒子数を貪食能と して同時に測定した.

\section{IgG, IgM, C 3 の測定法}

血漿はへパリン処理ヘマトクリット毛細管 (Dramond 社) を用い, $11,000 \mathrm{rpm}$ で 5 分間遠心 分離して得た。その際，発汗等による血液濃縮の 結果，血漿成分が見かけ上増加していないかどう か確認するため, ヘマトクリット值も記録した。 血墏の IgG, IgM, C 3 の各濃度は, ネフェロテッ ク TMシステム(京都第一科学)で測定した. IgGの 抗血清は抗ラット IgG ヤギ IgG(Cappel 社 55722) を，検量線用標準物質はラット IgG (Zymed 社 02-9602)を使用した. IgM の抗血清は抗ラット IgM ヤギ IgG (Cappel 社 55730)を, 標準物質は ラット IgM (Chemicon 社 pp 70) を使用した. C 3 の抗血清は抗ラット C 3 ヤギ IgG (Cappel 社
55730)を使用し，標準物質は入手でさなかったた め, 散乱光値(LSU)を測定値とした.

\section{E. 抗 SRBC 抗体価の測定}

抗 SRBC 抗体価は, 血清を $56^{\circ} \mathrm{C}, 30$ 分間の非 働化後, 赤血球凝集反応で測定した. まず非働化 血清の 2 倍希釈系列 $\left(2^{\mathrm{n}}: 2^{0}(=1)\right.$ 倍から $2^{11}$ 倍ま で）をU字形マイクロタイター用プレートの各穴 に $25 \mu l$ ずつ準備し， $0.5 \% \mathrm{SRBC}$ 溶液を各希釈血 清に $25 \mu l$ ずつ添加して混和した. 室温で 2 時間 反応させた後, 凝集陽性反応の終末点の希釈倍数 (n) を対数值 $\left(\log _{2} n\right)$ で表して赤血球凝集価（抗 $\mathrm{SRBC}$ 抗体価) とした.

\section{F. 統計処理}

測定結果は平均值士標準偏差で表し，群間の有 意差の検定には Student's t-test を行い, 個体内 (経時的測定間)の有意差の検定には Paired $t-$

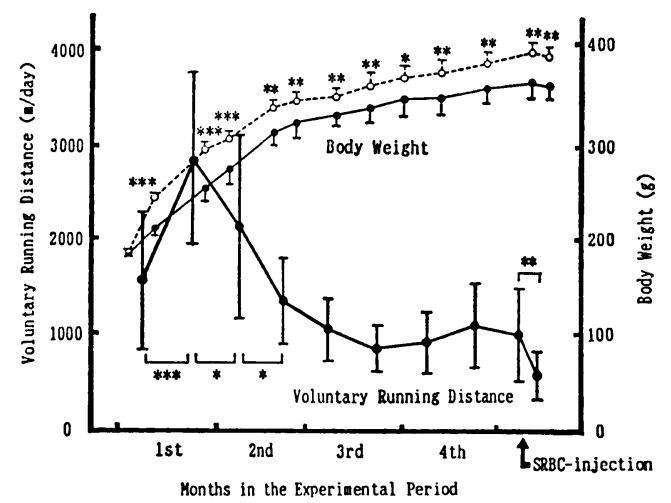

Fig. 1. Daily running distance in exercising rats $(O)$ and body weight in sedentary $(O)$ and exercise (๑) groups during the experimental period.

Daily running distance in the exercise group averaged $1422 \pm 387 \mathrm{~m} / \mathrm{d}$, reached a peak $(2839 \pm 888 \mathrm{~m} / \mathrm{d})$ within the lst month and waned over time, reaching a plateau (about $1000 \mathrm{~m} / \mathrm{d}$ ) on and after the $3 \mathrm{rd}$ month. Following SRBC-injection, the activity dropped off by $45 \%$ to the minimum quantity (555 \pm $236 \mathrm{~m} / \mathrm{d}$ ).

Body weights in the exercise group were significantly lower than those in the sedentary group consistently. Both parameters were so constant in the latter half of the experimental period that a proper condition was thought to have been set for evaluation of the chronic effects of regularly performed exercise. $\left(^{*}: \mathrm{p}<0.01,{ }^{* *}: \mathrm{p}<0.001,{ }^{* * *}: \mathrm{p}<\right.$ 0.0001 ) 
Table 1. Food intake, water intake and final body weight of rats in sedentary and exercise groups after 4-month period of voluntary exercise.

\begin{tabular}{lccc}
\hline \multicolumn{1}{c}{ Items (units) } & Sedentary $(\mathrm{n}=15)$ & Exercise $(\mathrm{n}=15)$ & $\mathrm{t}$-test \\
\hline Food intake $(\mathrm{g} /$ day) & $15.3 \pm 1.4$ & $17.8 \pm 1.7$ & $\mathrm{p}<0.001$ \\
Water intake (ml/day) & $19.2 \pm 2.1$ & $23.6 \pm 2.0$ & $\mathrm{p}<0.0001$ \\
Body weight $(\mathrm{g})$ & $393.5 \pm 13.4$ & $367.3 \pm 15.6$ & $\mathrm{p}<0.001$ \\
\hline & & & (Mean \pm S. D.)
\end{tabular}

While food and water intakes in the exercise group were much higher than those in the sedentary group, the increases in body weight were significantly inhibited in the exercise group. These results suggest that moderate regular exercise has a remarkable effect on prevention of obesity.

test を行った。相関関係には Pearson の相関係 数を用い,その有意性には無相関の検定を行った。

\section{III. 結}

果

\section{A. 㯰功量の推移}

運動量は, Fig. 1 のように飼有開始後 1 力月目 に $2,839 \pm 888 \mathrm{~m} / \mathrm{d}$ でピークに達し, それ以降は 减少傾向を示して 3 カ月目にプラトーに至った. 飼育期間の後半では, 運動群全体としての平均運 動量が $1,000 \mathrm{~m} / \mathrm{d}$ 程度で安定して推移したのみな らず，個体毎の運動量も一定に固定・習慣化し， 活発なラットは常に多い運動量を維 持する一方 で, 非活動的なラットは常に低い運動量で推移し た.このことは, 飼育 3 力月目と最後の 1 カ月 ( 4 力月目)の各 1 力月間の平均運動量を個体毎に 相関分析すると正の相関が認められ $(\mathrm{r}=0.665$, $\mathrm{p}<0.01, \mathrm{n}=15)$ ，また最後の 1 力月間と飼育全 期間の平均運動量の間にも正の相関が認められた $(\mathrm{r}=0.670, \mathrm{p}<0.01, \mathrm{n}=15)$ ことからも確認でき た.なお SRBC 接種後 4 日間の一日平均運動量 は，接種直前の $55 \%$ に当たる $555 \pm 236 \mathrm{~m} / \mathrm{d}$ まで 有意に減少した $(\mathrm{p}<0.001)$.

\section{B. 振食・掫水吾と体重の変化}

飼育 4 カ月後の $\mathrm{SRBC}$ 接種前に測定した 1 日 掑食量は, Table 1 のように非運動群 $15.3 \pm 1.4 \mathrm{~g}$ に対し運動群 $17.8 \pm 1.7 \mathrm{~g}$ となり, 運動群に有意 な高值が認められた $(\mathrm{p}<0.001) .1$ 日摄水量も， 非運動群 $19.2 \pm 2.1 \mathrm{~m} l$ に対し運動群 $23.6 \pm 2.0 \mathrm{~m} l$ で, 運動群に有意な高値が認められた $(\mathrm{p}<0.001)$. しかし SRBC 接種前の体重は, Table 1 のよらに
非運動群 393.5 $\pm 13.4 \mathrm{~g}$ に対し運動群 $367.3 \pm 15.6 \mathrm{~g}$ で, Fig. 1 でも一貫して認められたように運動群

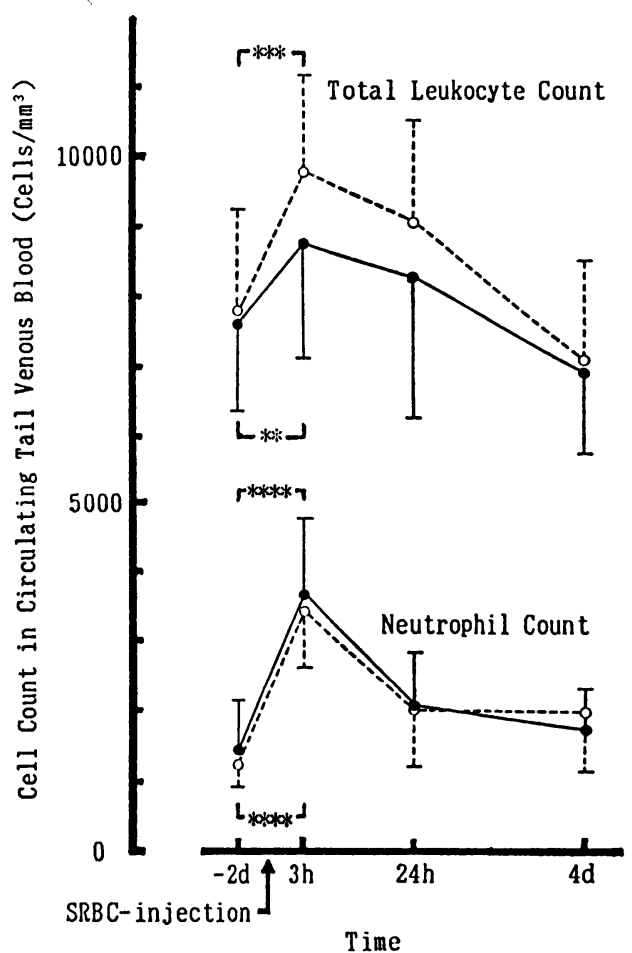

Fig. 2. Changes of total circulating leukocyte count and neutrophil count before and after intraperitoneal SRBC-injection in sedentary (O) and exercise (O) groups.

Total leukocyte count increased immediately after SRBC-injection in both groups and it was due to the increase in neutrophil count. But any significant differences were not seen in the numbers of the cells between the groups. ${ }^{* *}: \mathrm{p}<0.02, * * *: \mathrm{p}<0.01, * * * *: \mathrm{p}<$ 0.001 ) 
に有意な低値が認められた $(\mathrm{p}<0.001)$. したがっ て運動群のラットは慨・水を多く摂取していたに もかかわらず，体重の増加は抑制されていた。 た $\mathrm{SRBC}$ 接種後 4 日目の体重は, 接種直前に較 べ, 非運動群は $3.7 \mathrm{~g}$ 減少して $389.8 \pm 13.1 \mathrm{~g}$ に $(\mathrm{p}<0.05)$, 運動群は $2.7 \mathrm{~g}$ 減少して $364.6 \pm 16.6 \mathrm{~g}$ に $(\mathrm{p}<0.01)$, 両群ともに有意に減少した.

\section{C. 好中球の細胞数および貪食能・活性酸素産 生能の経時的变動}

静脈血中の総白血球数は, Fig. 2 のように $\mathrm{SRBC}$ 接種後 3時間目に両群ともに有意に増加し, それ以後は減少して 4 日目には接種前值まで戻っ た.この增加は同図から明らかなように好中球数 の急激な増加によるもので, 3 時間目にピークを 示した後, 24時間目には接種前值近くまで戻った. なおリンパ球数, 単球数, 好酸球数には, 有意な 変化は認められなかった。
$\mathrm{SRBC}$ 接種直後に両群ともに増加した好中球に ついて, 貪食能と活性酸素産生能を検討した結果 をFig. 3 に示した. まず好中球をブドウ球菌で刺 激しない場合の spontaneous NBT 還元スコアは, Fig. 3 (a) に示したよらに SRBC 接種後両群とも に有意に上昇し, 特に 3 時間目においては, 非運 動群 $24.0 \pm 12.3$ に対し運動群 $35.1 \pm 16.0$ となり, 運動群に有意な高值が認められた $(\mathrm{p}<0.05)$. 運 動群の好中球は 3 時間目にピークを示し, それが 非運動群で24時間目に示されたピークよりも高い ことから, 運動群では SRBC 接種後のより早い 時期に spontaneous NBT 還元能がより高く立ち 上がるという現象が認められた。

Fig. 3 (b) には, ブドゥ球菌で好中球を刺激し た場合の食食能と stimulated NBT 還元スコアを 示した. まず貪食能は, 接種後 3 時間目に両群と もに有意に低下したが，24時間目には回復し，以

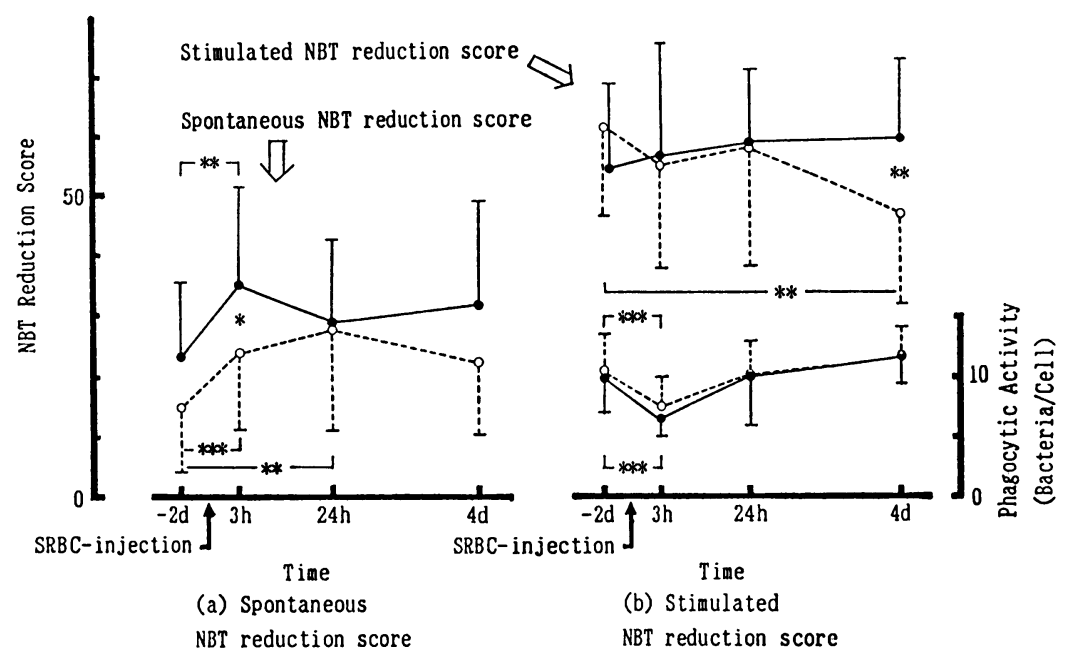

Fig. 3. Changes of neutrophil NBT reduction score (Superoxide-producing competence) before and after intraperitoneal SRBC-injection in sedentary $(\bigcirc)$ and exercise $(\bigcirc)$ groups. (a) Spontaneous NBT reduction score in the absence of stimulant ; The ability of circulating neutrophils to produce superoxide in the exercise group significantly rose high and that at once following SRBC-injection, suggesting that neutrophils were activated in vivo more rapidly against the invasion of foreign body in the exercise group.

(b) Phagocytic activity using St. aureus $209 \mathrm{P}$ and stimulated NBT reduction score; The ability of neutrophils to produce superoxide in response to in vitro stimulation with bacteria showed a remarkable downward trend in the sedentary group, though phagocytic activity was similar in both groups, suggesting that neutrophil bactericidal activity may be decreased in the sedentary group.

$(*: \mathrm{p}<0.05, * *: \mathrm{p}<0.02, * * *: \mathrm{p}<0.01)$ 
後一定の値を示した. 一方 stimulated NBT 還元 スコアは, 細菌の領食で刺激され, spontaneous NBT 還元スコアより例外なく高値を示した。運 動群の好中球では, SRBC 接種前から接種後 4 日 目まで一貫してほぼ同じ值の stimulated NBT 還 元スコアが維持されたのに対し, 非運動群では低 下傾向がみられ，接種前值が $61.5 \pm 14.3$ に対し 4

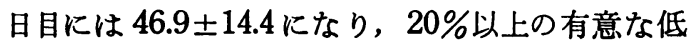
下が認められた（p<0.02）. さらに群間で比較し ても，4 日目の stimulated NBT 還元スコアは運 動群 59.7士13.0 に対し非運動群 $46.9 \pm 14.4$ となり,

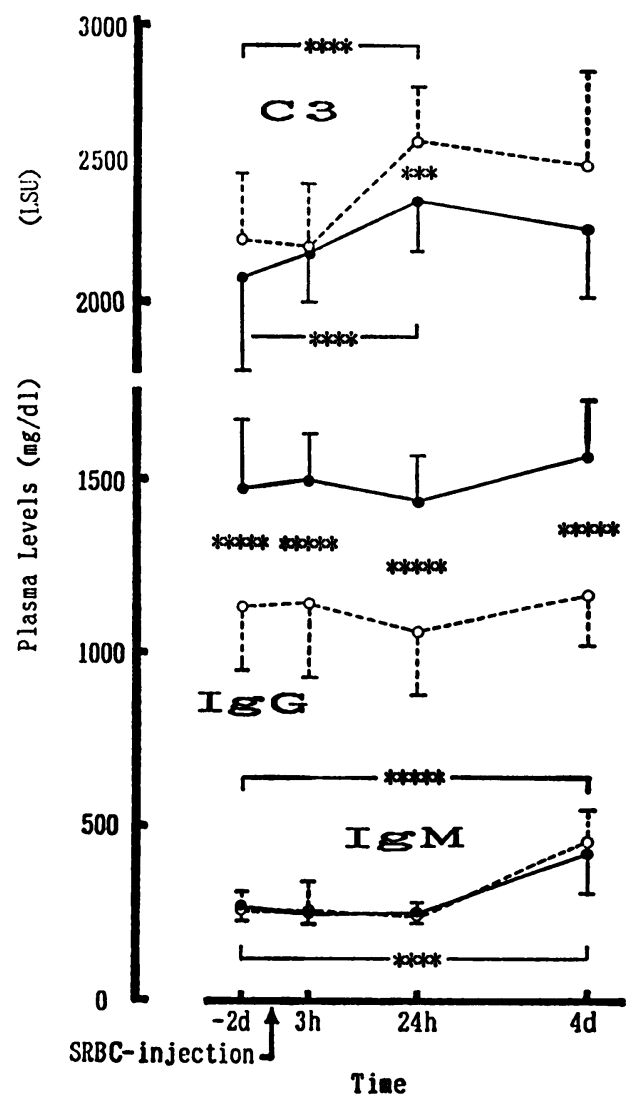

Fig. 4. Plasma levels of immunoglobulins and complement 3 before and after intraperitoneal SRBC-injection in sedentary $(O)$ and exercise (O) groups.

Plasma IgG levels in the exercise group were significantly higher by about $30 \%$ than those in the sedentary group consistently regardless of SRBC-injection. (***: $\mathrm{p}<0.01$, **** : $\mathrm{p}<0.001, * * * * *: \mathrm{p}<0.0001)$
非運動群に有意な低值が認められた $(\mathrm{p}<0.02)$.

\section{IgG, IgM, C 3 の経時的変動}

IgG 值は, Fig. 4 のように SRBC 接種前におい て非運動群 $1,132.7 \pm 177.8 \mathrm{mg} / \mathrm{d} l$ に対し 運動群 $1,473.0 \pm 195.8 \mathrm{mg} / \mathrm{d} l$ となり， 運動群に $30 \%$ 程度 の有意な高值が 認められた $(\mathrm{p}<0.0001)$. また $\mathrm{SRBC}$ 接種に伴ら変動はみられず，一貫してその 有意差が保たれたことからこの運動群における $\mathrm{IgG}$ 值の上昇は, SRBC 接種とは無関係にそれ以 前の長期にわたる運動習慣の影響と判断された。 一方 IgM 值は, 接種前から接種後24時間目まで は変動がみられず，4 日目に両群ともに有意に上 昇したが，群間に差は認められなかった。また C 3 值は運動群で全般的に低值を示し, 特に接種 後24時間目には非運動群 $2579.9 \pm 186.0$ に対乙運 動群 2369.6土176.5となり，運動群に有意な低值が 認められた $(\mathrm{p}<0.01)$.なお以上の結果は, SRBC 接種前のへマトクリット值に群間で差がなく，接 種後も全くその上昇がみられなかった点から，血 液濃縮の影響ではないことが確認された。

\section{E. 特異抗体産生能}

抗 SRBC 抗体価を SRBC 接種後 4 日目に測定 したが，非運動群 6.23士1.84 に対し運動群 5.03士 3.34 で有意差は認められなかった。たたし，抗 $\mathrm{SRBC}$ 抗体価と 4 日目の IgM 值との間に強い正 の相関が認められた $(\mathrm{r}=0.734, \mathrm{p}<0.0001, \mathrm{n}=30)$ ことから，接種後 4 日目の IgM 值の上昇は抗 $\mathrm{SRBC}$ 抗体産生反応の結果と推定された。

\section{IV. 考察}

\section{A. 運功贯の推移}

運動量は, 一旦増加して 1 カ月目にピークに達 してから，以後減少傾向を示し 3 カ月目にプラト 一に至った (Fig.1). ピーク時の 1 日平均運動量 は, 前回著者ら ${ }^{291}$ が検討した時は $965 \mathrm{~m} / \mathrm{d}$ であっ たが，今回はその約 3 倍の $2,839 \mathrm{~m} / \mathrm{d}$ となり，ま たプラトー時でも前回の約 2 倍の $1,000 \mathrm{~m} / \mathrm{d}$ 前後 に増加していた．この理由は，前回は別室を付設 した水車式回転籠を使用したのに対し，今回は別 室のない回転籠の中でラットが生活する飼育形態 に変更したため，運動する機会自体が増えたため 
と考えられる.しかしそれでも自発走運動モデル を用いた他の先行研究では, ラットが 1 日に $5 \mathrm{~km}$ あるいは $10 \mathrm{~km}$ 以上毎日運動していたといら報告 が多くみられるので291, 本研究は自発運動のなか でも実験条件としては軽度な運動量に位置づけら れる、またストレスや感染の防止を含め飼育環境 を厳密に規定すると, 各ラットの運動量が長期飼 育に伴って一定の水準で固定・習慣化することも 前回同様に認められ，このような実験条件下で得 られる自発運動量には, 各ラットの生理的な活動 要求性がよく反映されるという著者ら ${ }^{291}$ の推定は 妥当なるのと考兄られる. SRBC 接種に伴い自発 運動は強く抑制された(45\%減)が, Cannon ら4) も 自発運動の条件で飼育したマウスにサルモネラ菌 を感染させた際に同様な現象を認めており，この 自発運動の抑制は, 生体に備わる炎症時の防衛的 適応と推察される.

\section{B. 摄食・摄水量と体重の変化}

運動群のラットは, 慨・水を多く摂取していな がら，体重増加は逆に有意に抑制されており (Table 1，Fig. 1)，著者ら ${ }^{29)}$ が既に詳細に報告し た通り，脂肪組織の沈着防止を介した顕著な肥満 抑制効果が再現された。 また飼育期間後半の運動 量と体重の変化は, ともに極めて定常であり(Fig. 1)，その定常状態において諸機能を検討できたの で，適度な運動の慢性的な影響を評価する上で， 適切な実験条件が設定されていたものと考えられ る.

\section{C. 好中球の細胞数および食食能・活性酸秦産 生能の経時的変钦}

静脈血中の総白血球数は, 異物侵入の初期過程 で両群ともに有意に上昇したが，これは感染防御

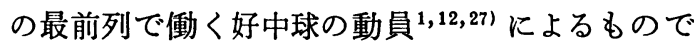
あった (Fig. 2). 細胞数の増加とともに, spontaneous NBT 還元能も両群ともに有意に上昇した (Fig.3(a)). この上昇は血液中の好中球で示され たことから，好中球が炎症局所へ浸潤する前の段 階で活性化され，血中から組織への血管透過や炎 症局所での異物排除を容易にするために適応現象

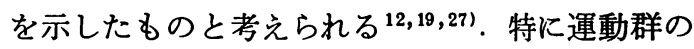
spontaneous NBT 還元能は, SRBC 接種に伴い
非運動群より早い時期に高い立ち上がりを示し, 運動群では好中球による防御網がより迅速に配備 される可能性が示唆された. 好中球の機能発現の 調節機構に関しては，それ自体では刺激にならず に, 後から加えられる異なる刺激に対して好中球 がより強力に反応をひき起こすプライミングとい ら現象が認められており ${ }^{1,19,33)}$ ，これは生体防御 機構の一環として好中球を修飾活性化する上で不 可欠な機序とも考えられている27. 本研究で示さ れたよらに，適度な運動といら軽度な生体刺激が 習慣的に繰り返されていると，異物侵入時に好中 球がより迅速でかつ強力に活性化されるという現 象は，このプライミング効果によって説明できる のではないかと考えられる.

次にその好中球の炎症局所での異物排除を想定 して, 実際に in vitro で生菌と反応させたところ, 貪食能は両群ともに同じ傾向を示した. しかし stimulated NBT 還元能は, 運動群では SRBC 接 種前後で一定に維持されていたものの, 非運動群 では低下傾向を示し，4 日目には接種前值よりも 20\%以上の有意な低下が認められた (Fig. 3(b)). また 4 日目の貪食能は両群ともにほぼ同じ值であ ったにもかかわらず, 非運動群の stimulated NBT 還元能は運動群と較べ有意な低值を示し, 非運動群の好中球では細菌の食食に引き続く活性 酸素の生成が効率的に連動して扣らず，殺菌能が 炎症の過程で低下していく可能性が示唆された.

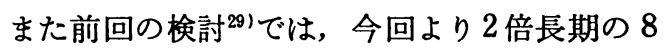
カ月間の自発運動条件において, 運動群の stimulated NBT 還元能に有意な低值が認められ, 今回 もSRBC 接種前に同様な傾向が示された (Fig. 3 (b)). 好中球は殺菌という感染防御上重要な役割 を担ら反面，標的異物への特異性が弱いため，生 体内で活性化されるとその強力な活性酸素の生成 能力によって正常組織をも破壊するという功罪二 面性をるつ ${ }^{351}$ ，好中球による活性酸素の過㮃生成 が諸疾患の原因となることは，虚血性心疾患 ${ }^{131}$, 高血圧時の臓器障害の進展 ${ }^{28)}$, 免疫フレルギー疾 患 ${ }^{22}$ 等における病態形成の機序として急速に解明 されつつある ${ }^{191}$. したがって，運動習慣によって 非感染時に好中球の活性化が抑制され，その機能 
が安定化していることは, 生体にとってプラスに 働くものと考えられる. しかし一旦感染等の異常 が生じると，好中球の機能調節機構が，それ以前 の適度な運動習慣によって修飾されている結果, 非感染時の機能だけでは推定できない積極的な適 応を示す可能性が, 今回の検討より示された.

\section{IgG, C 3 の経時的変動}

自然抗体としてオプソニン活性を担う IgG は, 血液濃縮による見かけ上の増加や SRBC 接種と は無関係に, 運動群で一貫して $30 \%$ 程度の有意な 高値を示した (Fig. 4). 適度な運動習慣によって 安静時の IgG 值が増加したという報告は複数あ るが, IgG 值が感染頻度に伴い上昇したり, 加龄 に伴い自己抗体の性格をもって増加するため, 運 動習慣によるその増加が健康にプラスに働くのか 否かについて議論がなされてきだ,22). しかし Nieman ら ${ }^{251}$ は, 15週間の速歩運動の継続により IgG 值が $20 \%$ 以上増加したのみならず，その増加 が呼吸器感染症䍜患期間と負の相関を認めたこと から，適度な運動習慣による IgG 值の増加は感 染抵抗力の強化につながると報告している。また Fröhlich ら ${ }^{81}$ は, 運動選手の海外遠征時の感染予

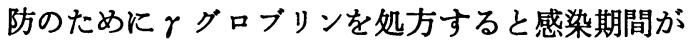
対照群の $1 / 3$ に減少したと報告しており，このこ とからも IgG 值の増加は感染防御に有効に働く ものと考えられる. また本研究では, 感染を防ぐ ために SPF ラットをセミバリア室内で飼育して おり，風邪や下凩等の異常は認められなかったの で, 運動群でのみ感染によって IgG 值が増加し たとは考えられない.したがって，運動習慣が何 らかの機序により IgG 值を増加させ, 生体防御 機構を強化している可能性が，今回動物実験でも 示された.

補体系の中心成分 C 3 は, 運動群で全般的に低 值を示し, 特に SRBC 接種後 24時間目には有意 差が認められた。運動習慣と補体系に関しては, Nieman ら ${ }^{23)}$ が中年ランナーにおける C 3, C 4 值 の低下を報告しており, 本研究でも同様な傾向が 認められた. 補体系は感染防御において重要な役 割を担ら反面, 炎症時の組織障害にも関与してお ク, また本研究も含め補体価等の機能活性につい
てはまだ検討されていないため，この現象が健康 にプラスに動くか否かについては現段階では十分 に言及できない。

\section{E. 特異抗体産生能}

運動習慣が in vivo の抗体産生能に及ぼす影響 は，ヒトでは実験手法上の制約があるため動物実 験で検討されてきたが，一次応答では影響がなか ったといら報告が多く5,14,21)，二次応答時に効果 が認められたといら報告が1つあるのみである ${ }^{18)}$. 本研究でもSRBC 接種に対する一次応答には抗体 価に差が認められず, IgM 值の上昇も同様であっ たことから，運動習慣の影響は一次抗体産生能に は影著にあらわれないものと推察される。

\section{V. 結 論}

適度な運動習慣によって, 生体防御機構が強化 されるか否かを検討するために，ラットを自発運 動の条件下で 4 カ月間飼育した後, SRBC を接種 して実験的に免疫応答を誘導した。感染防御を担 ら主要因子および機能の变動を経時的に測定した ところ, 免疫応答以前の非特異的な生体防御機構 において,いくつかの積極的な適応が認められた。

1）静脈血中の好中球は, SRBC 接種後 3 時間 目に細胞数・活性酸素産生能ともに有意に上昇 し, 特に運動群の活性酸素産生能は有意な高值を 示し, かつその立ち上がりが非運動群より早かっ た。これは適度な運動習慣による好中球のプライ ミング効果を反映していると考えられ，運動群で は異物接種に伴い好中球がより迅速でかつ強力に 活性化される可能性が示唆された。

2) その好中球の炎症局所での異物排除を想定 して実際に細菌と反応させたところ，細菌食食に 伴ら活性酸素の生成は, 運動群では接種後 4 日目 まで一定に維持されたが，非運動群では接種前值 と較べ 4 日目には $20 \%$ 以上の有意な低下を示し， かつ運動群と比較しても有意な低值が認められ た.このことから非運動群の好中球では貪食にひ き続く活性酸素の生成が効率的に連動して扣ら ず, 殺菌能が炎症の過程で低下していく可能性が 示唆された.

3) 血漿の IgG 值は, SRBC 接種とは無関係 
に運動群で30\%程度の有意な高值を示し, 運動習 慣による生体防御機構の強化が示唆された。

4) SRBC 接種に対する特異抗体産生能につい ては, 抗 SRBC 抗体価ならびに IgM 值の上昇を 検討したが，顕著な影響は認められなかった。

\section{謝 辞}

稿を終えるにあたりご指導ご助言をいたたいた帝京 大学医学部第一内科松田重三助教授, 日本大学医学部付 属駿河台病院臨床検査部後藤 清主任, 女子栄養大学衛 生学教室林 修助教授, 国立公衆衛生院労衝衛生学部内 山跾雄部長, 同熊江 隆室長に心よりお礼を申し上げま す. また測定機器等ご援助ご協力下さいました早稲田大 学人間科学部太田富貴男教授, 村岡 功教授, 山内兄人 教授に深謝致します。

なお，本研究の要旨は，第62回日本衛生学会総会(1992 年，要媛）に打いて報告した。

\section{(受付 平成 4 年 7 月 7 日)}

\section{文献}

1）赤尾正樹, 小坂二度見 (1989)：感染と好中球。臨床 麻酶，13，199-204.

2) Asgeirsson, G. and Bellanti, J.'A.(1987) : Exercise, immunology, and infection. Semin. Adolesc. Med., 3, 199-204.

3）綾部光芳, 原 昭典, 七條茂樹, 佐川公矯, 横山三 男(1988) : シ ョカーの免疫能. 体力研究, 69, 1-7.

4) Cannon, J. G. and Kluger, M. J. (1984) : Exercise enhances survival rate in mice infected with Salmonella typhimurium (41830). Proc. Soc. Exp. Biol. Med., 175, 518-521.

5) Davis, M. A., Kendrick, Z. V. and Paolone, M. (1986): The measurement of antibody response to influenza virus vaccine in aerobically trained mice. Med. Sci. Sports Exerc., 18, S9.

6) Digregorio, K. A., Cilento, E. V. and Lantz, R. C. (1987) : Measurement of superoxide release from pulmonary alveolar macrophages. Am. J. Physiol., 252, C 677-C 683.

7) Fitzgerald, L. (1991): Overtraining increases the susceptibility to infection. Int. J. Sports Med., 12, S5-S 8.

8) Fröhlich, J., Simon, G., Schmidt, A., Hitschhold,
T. and Bierther, M. (1987) : Disposition to infections of athletes during treatment with immunogloblins. Int. J. Sports Med., 8, 119.

9) 月刊 Medical Technology 編 (1985): 細胞性免疫 機能検查法のすべて，初版．医歯薬出版，東京，1219.

10) Good, R. A. and Fernandes, G. (1981) : Enhancement of immunologic function and resistance to tumour growth in Balb C mice by exercise. Fed. Proc., 40, 1040.

11）池上晴夫(1987)：運動と健康. 公衆衛生, 51, 1720.

12) 今村隆寿, 神原 武(1991): 炎症過程に打ける好中 球，マクロファージの動態. 生体防御, 8, 85-94.

13）葛谷恒彦, 藤 久和, 多田道彦(1991)：心筋虚血と オキシラジカル。実験医学，9，44-48.

14) Keast, D., Cameron, K. and Morton, A. R.(1988) : Exercise and the immune response. Sports Med., 5, 248-267.

15）喜多尾浩代, 山田 尚, 河野一郎, 桑島士郎, 田中 喜代次, 松田光夫, 中塘二三生, 前田如矢(1989)： 運動の継続が免疫機能に及ぼす影響. 体力研究, 72, 70-80.

16）河野一郎(1992)：運動と免疫. 体力科学, 41, 139146.

17) Kumae, T., Sugawara, K., Machida, K. and Shimaoka, A. (1987): Changes in serum immunoglobulin levels and neutrophilic phagocytosis after exercise. Jpn. J. Phys. Fitness Sports Med., 36, 61-67.

18) Liu, Y. and Wang, S. (1987) : Enhancing effect of exercise on the production of antibody against Salmonella typhi in mice. Immunol. Lett., 14, 117120.

19）水上茂樹, 柿沼カ\%子, 竹重公一朗(1990)：白血球 と生体防御. 初版. 講談社, 東京.

20) 森口 覚, 栢下 淳, 岡田 悟, 酒井徹, 岸野泰 雄(1990)：加龄に伴う細胞性免疫能の低下に対する 栄養および運動の奻果. 体力研究, 75, 144-151.

21）長尾害樹, 高居百合子, 小野三嗣 (1991)：発育期 ウスの運動とスピルリナ (Spirulina platensis) 摄取 がハブテン特異的免疫応答に及ぼす影䉕. 体力科学, 40, 187-194.

22) Nehlsen-Cannarella, S. L., Nieman, D. C., Balk- 
Lamberton, A. J., Markoff, P. A., Chritton, D. B., Gusewitch, G. and Lee, J,. W. (1991) : The effects of moderate exercise training on immune response. Med. Sci. Sports Exerc., 23, 64-70.

23) Nieman, D. C., Tan, S. A., Lee, J. W. and Berk, L. S.(1989) : Complement and immunogloblin levels in athletes and sedentary controls. Int. J. Sports Med., 10, 124-128.

24) Nieman, D. C., Nehlsen-Cannarella, S. L., Markoff, P. A., Balk-Lamberton, A. J., Yang, H., Chritton, D. B., Lee, J. W. and Arabatzis, K. (1990) : The effects of moderate exercise training on natural killer cells and acute upper respiratory tract infections. Int. J. Sports Med., 11, 467-473.

25) Nieman, D. C. and Nehlsen-Cannarella, S. L. (1991): The effects of acute and chronic exercise on immunogloblins. Sports Med., 11, 183-201.

26) Roebuck, B. D., McCaffrey, J. and Baumgartner, K. J.(1990) : Protective effects of voluntary exercise during the postinitiation phase of pancreatic carcinogenesis in the rats. Cancer Res., 50, 68116816.

27）佐藤英介，秋丸国広，内海耕俈，内海俊彦，井上正 康 (1992)：疾患時飞おける好中球の代謝動態. 代謝, 29, 15-23.

28) Schmid-Schönbein, G. W., Seiffge, D., DeLano, F.
A., Shen, K. and $Z$ weifach, B. W. (1991) : Leukocyte counts and activation in spontaneously hypertensive and normotensive rats. Hypertension, 17, 323-330.

29）鈴木克彦, 町田和彦, 刚屋美枝子(1992)：ラットの 自発走運動モデルの基礎的検討および健康指標に及 ぼす慢性影篃. 日衛誌, 47, 939-951.

30）朝永万佐男 (1976)：好中球の Nitroblue-Tetrazolium (NBT) 還元能に関する研究, I 組織化学的半 定量化の試み。臨床血液, 17, 1266-1275。

31) Ueda, N., Kayashita, J., Moriguchi, S. and Kishino, Y. (1990) : Effect of dietary protein levels on immune function of exercised rats. Nutr. Res., 10, 429-437.

32）吉川敏一, 谷川 徹, 近藤元治 (1990): 活性酸素と 疾患一炎症を中心として一。感染・炎症・免疫, 20, 247-256.

33) Warren, J. S., Kunkel, S. L., Johnson, K. J. and Ward, P. A. (1987): In vitro activation of rat neutrophils and alveolar macrophages with IgA and IgG immune complexes. Am. J. Pathol., 129, 578-588

34）渡辺誠一郎(1990)：長期継続運動が中高年者の免疫 能に及ぼす影敕。愛媛医学, 9, 400-409.

35) Weiss, S. J.(1989) : Tissue destruction by neutrophils. N. Engl. J. Med., 320, 365-376. 